\title{
MI TÖRTÉNIK A FÖLDRAJZÓRÁKON? LÁTRAJZ A FÖLDRAJZTANÍTÁSRÓL EGY FELMÉRÉS ÉS A SZAKMÓDSZERTANI TANÓRÁK TAPASZTALATAI ALAPJÁN
}

WHAT IS TAKING PLACE ON GEOGRAPHY LESSONS? A SKETCH OF GEOGRAPHY EDUCATION BASED ON A SURVEY AND ON THE EXPERIENCES OF CLASSES ON THE DIDACTICS OF GEOGRAPHY

\section{MAKÁDI MARIANN}

Eötvös Loránd Tudományegyetem TTK Földrajz- és Földtudományi Intézet Földrajz szakmódszertani csoport makadim@caesar.elte.hu

\begin{abstract}
The geography as subject cannot accomplish its unique attitude-forming and knowledge-transferring role in the Hungarian schools since decades. Not only because of the discrepancy that on the one side enormous quantity of the syllabus should be elaborated, while on the other side the curriculum provides disproportionately few time for this purpose, but also therefore, because the geography education and learning do not rest upon competence-developing methods. A survey related to the customs of geography learning proves that there is a backwardness; a considerable part of the teachers use still frontal methods, while the students cannot learn to reflect and cannot learn, how they must learn.
\end{abstract}

Keywords: geography education, learning geography, analytical knowledge model, practical knowledge model, questionnaire, culture of methodology, teaching-learning techniques, frontal teaching, classroom and home learning

\section{Az emlék örök csapda?}

\author{
„Az emlék örök csapda. Ki érkezik, ki jár. \\ Osztálytablók örzik a régi iskolát. \\ Álmomban sok óra, kinyílt a világ. \\ Barna köpenyben a dobogón áll a földrajztanár.
}

Kívülröl fújtuk a városokat, sok afrikai államot.

Beutazta az egész világot. Kanadát, s Albániát.

Hegyekről, tengerekről feleltünk, mutatott sok csodát.

A határokat átírták, de maradt a földrajztanár..."

(Koltay Gergely, Kormorán zenekar)

...S maradt a módszer is, aminek segítségével meg akarjuk ismertetni a világot a tanulókkal. Csakhogy ami évszázadokon át jól működött, az ma egyáltalán nem. Zúdulnak ránk az információk, amiket befogadni és feldolgozni, egymáshoz illeszteni nincs időnk, rohanunk az újabb benyomások, információk felé. De erről az iskolában szinte nem veszünk tudomást. Mintha az osztályterem ajtajának becsukásával kizárnánk a valóságot, és tanításunkban a Pascal-féle gondolkodást alkalmazzuk: a tudás olyan, mint egy fa, minél nagyobb és 
szerteágazóbb, annál erősebb a kapcsolata az ismeretlennel. A tudást még mindig tények, fogalmak, elvek, elméletek ismereteként értelmezzük, azt képzeljük, hogy minél nagyobb a halmazuk, annál többet tudunk a világról (analitikus tudásmodell). Értetlenül szemléljük, ahogyan a gyerekek egyszerre több dologra figyelnek, többfélét csinálnak és az müködik. Számukra nem izgalmas a tudás fájának ágait, gallyait szisztematikusan vizsgálni. Türelmetlenek, ha néhány percen belül nem éri őket valami újszerü inger, nem kell valami más tevékenységet végezniük. A dolgok értelmét és a praktikumot keresik. Hányszor teszik fel a kérdést: mire való ez, miért kell ezt megtanulni? Ök társadalmi tapasztalati alapon felismerték, hogy a tényismeretek halmozásának kevés értelme van, az információk megszerzése és feldolgozása a fontos. Vagyis ösztönösen keresik azokat a „,fogásokat”, „praktikákat”, amikkel az információk értelmes egésszé rakhatók össze. Őket a problémák izgatják, amiket le kell győzni, azaz meg kell válaszolni. S ha ezt együtt tehetik, még jobb, mert átérezhetik, hogy közösen „legyözhetetlenek”, de legalábbis okosabbak, mint külön-külön. Ök a praktikus tudásmodell szerint müködnek, amiben a tények közötti kapcsolatok, összefüggések és következmények felismerése, a nagyságrendek, a tendenciák érzékelése, a viszonylagosság értelmezése és a felhasználhatóság a hasznos ismeret.

Az egyetemen földrajz szakmetodikát oktatóként nap mint nap szembesülök a leendő földrajztanárok módszertani szkepticizmusával. A hallgatók érdeklődők az új tanítási és tanulási módszerek iránt, sok-sok ötletük van, kommunikációjuk és tanulásuk során egyre hatékonyabban alkalmazzák a digitális eszközökhöz kapcsolódó módszereket. Ám amikor arról van szó, hogy hogyan lehet mindezt a tanítási folyamatban hasznosítani, lezárnak. Szinte csak a gimnazistákban és a hagyományos tanítási gyakorlatnak megfelelő analógiákban, leginkább a frontális tanítási és tanulási módszerekben gondolkodnak. Az ettől eltérőekre (különösen a kooperatív és a kollaboratív tanulási technikákra) úgy tekintenek, mint valami esetleges, különleges helyeken kipróbálhatóra, de semmiképpen sem mint általános tanítási-tanulási módszerekre. Van hozzá ideológiájuk is: minket is frontálisan tanítottak, s lám, múködött, itt vagyunk az egyetemen. Meg egyébként sincs rá idő a heti 1-2 földrajzórán, 35 tanulóval nem működhet, és igen sok felkészülést kíván... - sorolhatnám még a sztereotíp kifogásokat. Ez a jelenség persze messzire vezet. Ebben a tanulmányban csak azokkal a vetületeivel foglalkozom, amelyek érintik a tanulási módszereket.

\section{Hogyan tanuljuk a földrajzot?}

E tanulmány tartalmi elözménye a földrajzoktatás helyzetének megismerése céljából a Magyar Tudományos Akadémia X. (Földtudományok) Osztálya Földrajz Tudományos 
Bizottságai Oktatási Albizottsága kezdeményezésére 2009-ben készített helyzetfeltáró kérdőíves felmérés. Részét képezte a földrajztanárok módszertani kultúrájának és a tanulók földrajztanuláshoz szükséges kompetenciaszintjének feltérképezése (MAKÁDI M. 2011, MAKÁDi M.-HoRvátH G. 2011). Akkor kedvezőtlen kép alakult ki a földrajzórákon folyó tanulásról. Sajnos a tapasztalatok azt mutatják, hogy az azóta eltelt nyolc évben nem sok minden változott, pedig új tantervek (Nemzeti alaptanterv 2012, kerettantervek 2012), kísérleti és újgenerációs tankönyvek (Földrajz a 7., 8., 9., 10. évfolyam számára, OFI 20152016), új szemléletű földrajz szakmódszertani tankönyvek (FARSANG A. 2011, MAKÁDI M.-Farkas B. P.-Horváth G. 2013a, 2013b, Makádi M. 2015a) készültek. Annak ellenére sem, hogy a földrajztanárok többsége belátja, nem eredményes a munkája. Ennek okát azonban nem feltétlenül a tanítási és a tanulási módszerekben keresi.

A kedvezőtlen tapasztalataim megerősítése (vagy reményeim szerint gyöngítése) céljából 2016. év végén felmérést végeztem általános és középiskolai tanulókkal jelenlegi, valamint földrajztanár szakos hallgatókkal múltbeli földrajztanulási szokásaikról. A kérdőíves felmérést online végeztük, az önkéntes válaszadók (419 tanuló és 41 hallgató) Google Drive felületen töltöttek ki egy kérdőívet. A kérdések nagy része az egységes értelmezés és a kiértékelhetőség érdekében választásos típusú volt, egy vagy több (sokszor 10-15) lehetőségből kellett választani, esetenként többet is megjelölni. Néhány nyílt végű kérdés is szerepelt annak érdekében, hogy a válaszadók pontosabban kifejezhessék a gondolatukat, az érzelmüket, az attitűdjüket (pl. mit szeretsz vagy nem szeretsz legjobban a földrajzban, mi ragadja meg a figyelmedet egy tankönyvi leckében? hogyan tanulod otthon a földrajzot?). Nem kívántam megszabni, hogy mely településeken, mely iskolatípusokba és évfolyamokra járók válaszoljanak, de csak a 7-10. osztályokra terjesztettem ki, hiszen önálló földrajz tantárgy csak ekkor van. A válaszolási hajlandóság alapján azonban a felmérés alapvetően a középiskolai földrajztanulásba engedett bepillantást. A válaszadóknak csak alig több mint egynegyed része volt általános iskolás korú (1. ábra), döntő többségük gimnazista (84,4\%) (2. ábra). A fiúk (41,8\%) és a lányok (52,2\%) aránya ugyan kissé eltérő volt, de nemek szerint csak azokat a tapasztalatokat választom szét, amelyeknek van relevanciája.

\section{Van-e értelme földrajzot tanulni?}

Érdemes abból kiindulni, hogy a tanulók mennyire tartják hasznosnak a tantárgyat, mert a róla kialakult kép nagyban összefügg azzal, hogy mit láttat meg a tanár a praktikusságából. A tanulók összességében 3,67-es osztályzatot adtak rá. A kevésbé jó tanulói megítélés (1-3 osztályzat) esetében egyértelműen kimutatható az összefüggés a 


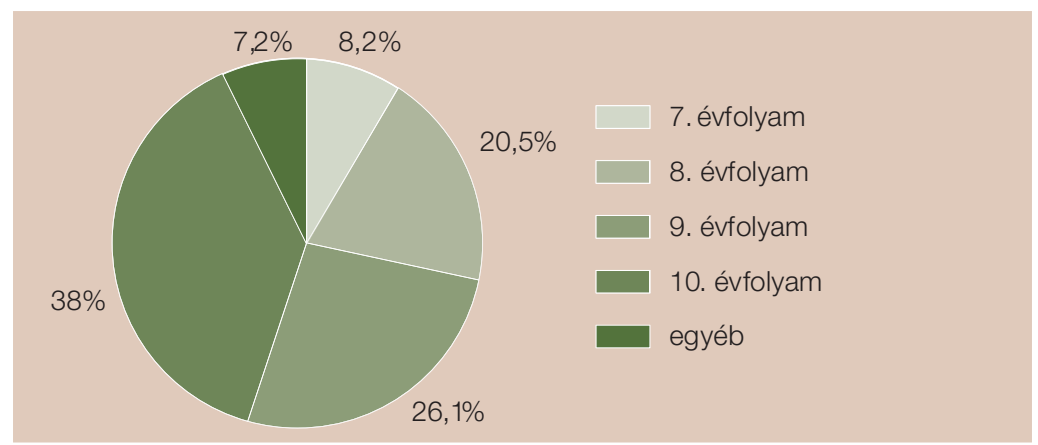

1. ábra. A felmérésben részt vevő tanulók megoszlása évfolyamonként

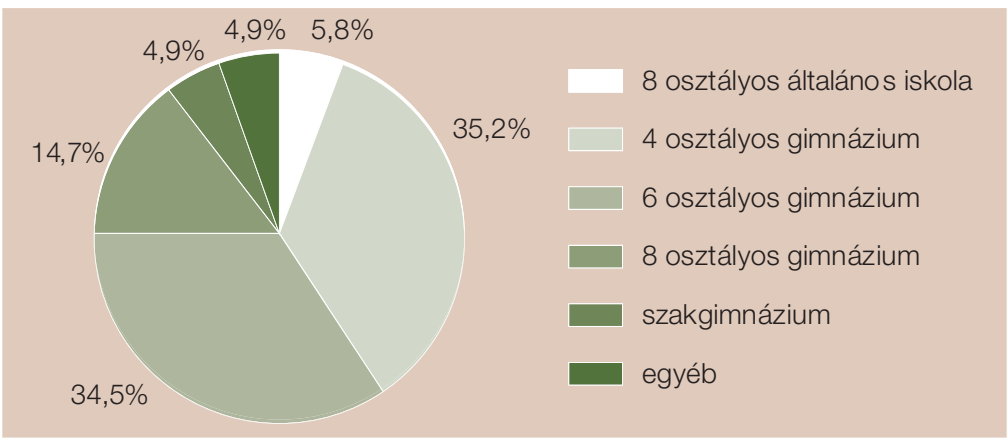

2. ábra. A felmérésben részt vevő tanulók aránya iskolatípusonként

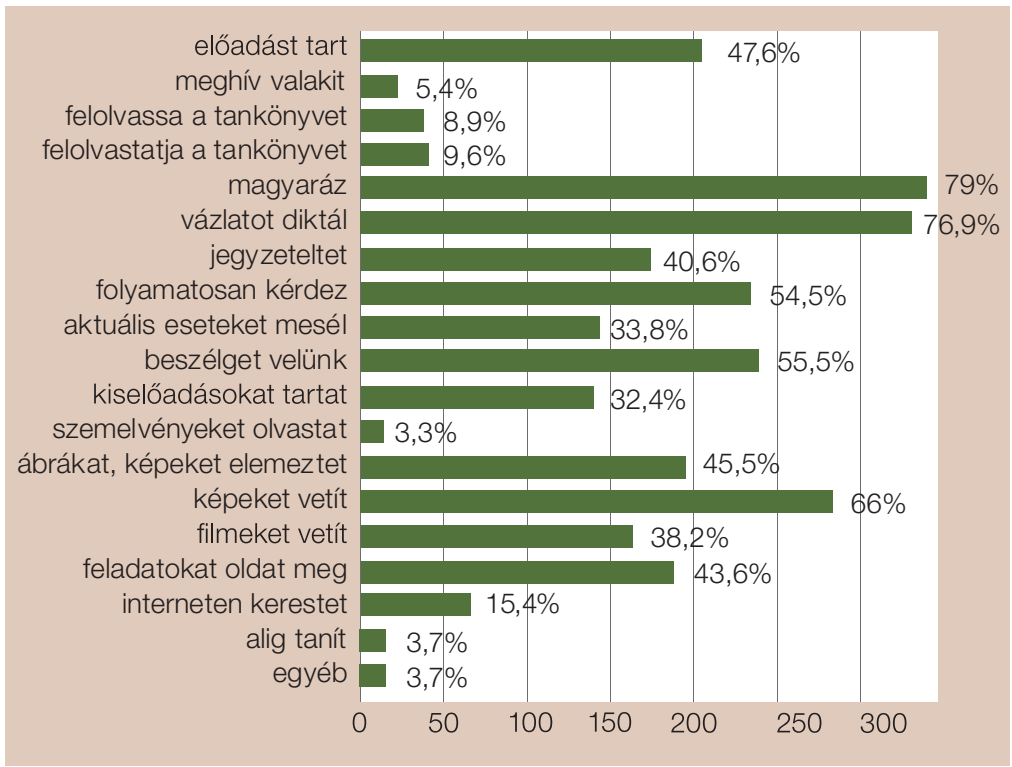

3. ábra. A földrajztanár által alkalmazott módszerek gyakorisága az összes tanulói mintában 
tanuláskor alkalmazott módszerekkel (3. ábra). A tanárok többnyire vázlatot diktálnak (66,9\%), előadást tartanak (41,2\%), jegyzeteltetnek (36,0\%), vagy szélsőséges esetben a tankönyvi szöveget olvastatják fel (12,2\%). Akik viszont 4-nél jobb osztályzatot adtak $(61,8 \%)$, azok tanárai beszélgetnek $(79,2 \%)$, aktuális eseteket beszélnek meg a tanítványokkal $(80,8 \%)$, interneten kerestetnek $(71,6 \%)$ vagy csoportokban dolgoztatnak (83,2\%). Érdekes módon bár a tanár szakos hallgatók lényegesen magasabbra értékelték a földrajz hasznosságát $(4,78)$, ugyanazokat a tanítási módszereket említették a legnagyobb gyakorisággal. Emögött nyilván van már némi intellektuális belátás, helyesen értelmezik a tantárgy szerepét a köznevelési rendszerben. Ugyanakkor a tanárképzés szempontjából nehézséget jelent, hogy a tanítási-tanulási módszereket és a tantárgyról kialakult képzeteket nem hozzák összefüggésbe egymással.

Kapcsoljuk ide a tanulók földrajzhoz való érzelmi viszonyát! Összességében a 10 fokozatú skálán 7-esre értékelték, amivel még elégedettek is lehetnénk. Feltűnő, hogy a lányok értékelése kevésbé pozitív $(5,8)$, mint a fiúké $(8,6)$. Magyarázható ez a középiskolai válaszolók nagy arányával, hiszen a tananyag ebben az életkorban alapvetően rendszerszemléletủ és nagy arányban gazdasági tartalmú, ami - tapasztalataim szerint jobban megfelel a fiúk érdeklődési körének. A viszonylag magas érzelmi értékhez tartozó indokok azonban elgondolkodtatók. A válaszolók egyharmad része a „mit szeretsz benne?" kérdésre vagy nem válaszolt, vagy azt válaszolta, hogy "semmit”. Mások inkább a tananyag tartalma felöl közelítették meg a kérdést, többségük a társadalom-földrajzi vagy a regionális földrajzi témákat jelölte meg. Kevés válasz vonatkozik a tananyag és a tanítás megközelítésmódjára vagy módszerére, például az, hogy azért szereti, mert a mindennapokkal foglalkozik (12,2\%), mert térképolvasásra épül (18,9\%), vagy mert tanulása közben gondolkodni kell (15,4\%).

A „mit nem szeretsz a földrajzban?” kérdésre viszont inkább a természetföldrajzi témákat (pl. kőzetek, talaj, éghajlat) és a gazdasági és pénzügyi ismereteket nevezték meg. Feltünően sokan indokolták mennyiséggel, például sok felesleges tényt $(68,2 \%)$ és szakkifejezést $(76,2 \%)$ kell megtanulni, magas a topográfiai követelmény $(45,7 \%)$, sokat kell tanulni $(73,4 \%)$. Ez jelzi egyfelől a földrajz mint tantárgy egyik alapvető problémáját: a feszítő ellentmondást a tananyag mennyisége és a feldolgozására fordítható időkeret között, különösen a 2007-es, majd a 2012-es tanervi változások óta. Megjegyzendő, hogy az óraszámok csökkenése nem járt a tananyag ésszerü újragondolásával. A tantervek és a tankönyvek bizonyos tartalmi elemek esetében ugyan próbáltak egyszerüsíteni, a „szisztematikusan végigtanítjuk a Földet” szemlélet felől 
a modellszerűség (pl. tipikus tájak, földrajzi övezetességi és gazdasági modellek), az esettanulmányokon, példákon keresztüli megismerés felé tolni a tanulási folyamatot. Ez azonban csak kis mértékben hozott eredményt. A tanárok egy része ugyanis maga csempészi vissza a hagyományos megközelítésű és tartalmú, terjedelmü tananyagot, mondván, ez nem maradhat ki, hiszen mindig tanítottuk (pl. bizonyos országok leíró földrajza), mindig így tanítottuk (pl. vaktérképrajzoltatás és rendszeres térképi, gazdasági funkció-beszámoltatás).

Terjed az a jelenség, hogy a földrajztanár nem használtatja az új szemléletű tankönyvet, arra hivatkozva, hogy az többletmunkát jelent a számára, például új óravázlatot kell készítenie, új feladatokat kell kitalálnia, miközben a tankönyvek és a munkafüzetek telis-tele vannak gondolkodtató, érdekes és a fejlesztési követelményekkel összhangban lévő feladatokkal. A válaszadók kétharmad része módszerbeli problémákkal hozta kapcsolatba azt, hogy nem szereti a földrajzot (bár az előzőeknek is van módszertani összefüggése), például „magolni” kell (54,1\%), „a tanár gyorsan leadja a tananyagot és nem törődik azzal, hogy megértjük-e”, sok az ellenőrző dolgozat és felelés $(68,4 \%)$, unalmasak az órák (39,7\%). Be kellene látni, a földrajz annyira változatos tartalmú tantárgy, hogy szinte minden témakörét más módszerrel kell tanítani, mert más logikai kapcsolatokra épül, más tartalmi vagy fejlesztési feladata van. A feldolgozandó témák tartalmához, megközelítésmódjához, a tartalomhoz kapcsolódó tevékenységrendszerhez kellene igazítani a feldolgozási módszereket, nem pedig a tanár egyedi tanítási sablonjához, stílusához.

\section{A 21. századból vissza a 20. századelőre}

A fenti válaszok jól reprezentálják a földrajztanári módszertani kultúra hiányosságait. Ugyanerre utalnak a tanítás-tanulás folyamatában használt eszközökkel kapcsolatos válaszok. Olyan eszközöket sorolt fel a kérdőív, amelyek nélkül szakmódszertani szempontból nem lehet eredményesen földrajzot tanulni a 21. században, és ezek használatának gyakoriságát is értékelni kellett négy kategóriába (minden órán, gyakran, ritkán, soha) sorolva (4. ábra). Látható, hogy új szokások kezdenek kibontakozni az iskolában. Csökken a nyomtatott taneszközök használatának mértéke. Szinte hihetetlennek tűnik, hogy a földrajzórán a tanulók egynegyed része nem használ atlaszt, sőt falitérképet, földgömböt még kevesebben. Sajnos saját tapasztalataim szerint egy részüknek nincs is földrajzi atlasza (mondván, nem fér bele a tankönyvkeretbe). Az iskolában a tanárok egy része még csak-csak gondoskodik 


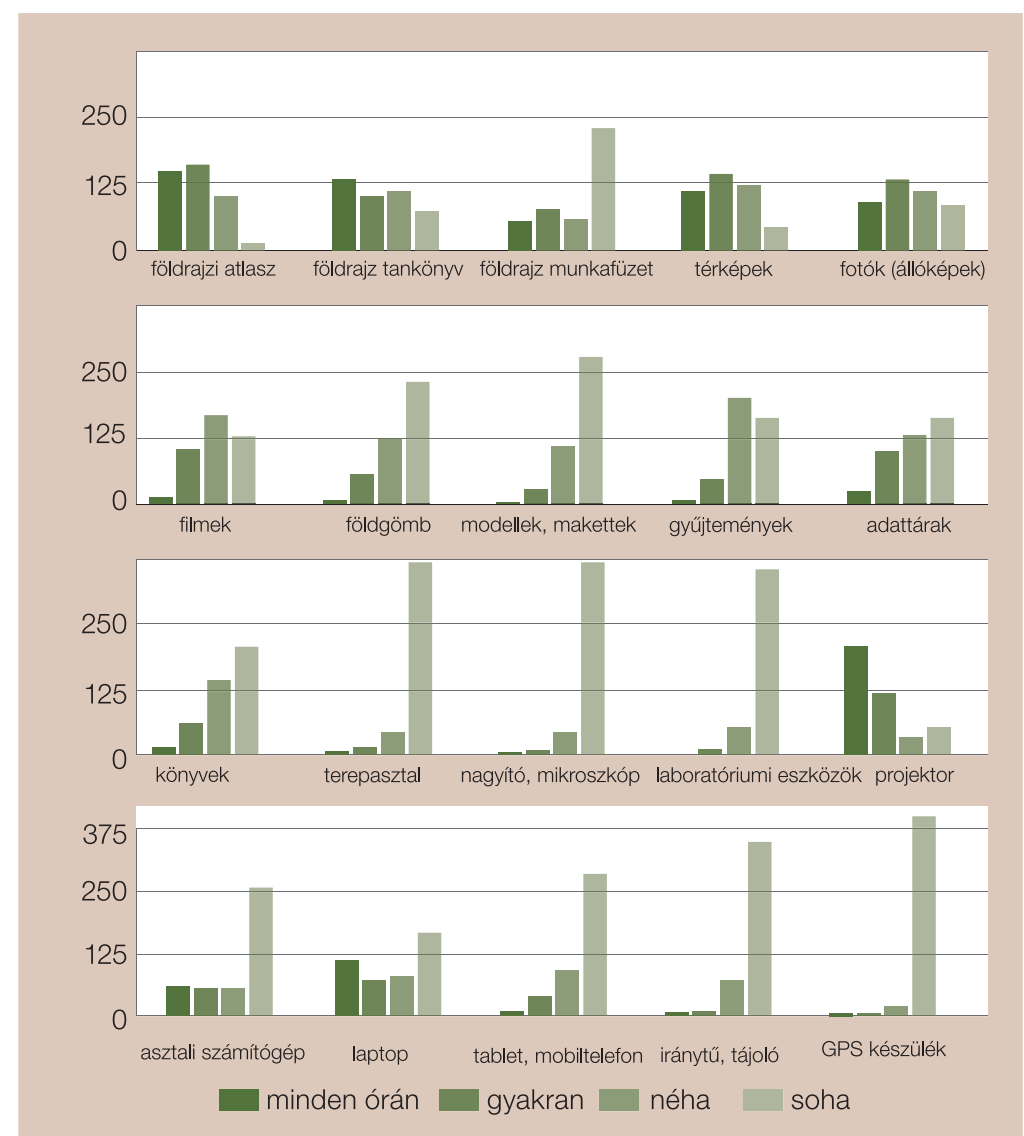

4. ábra. Az egyes eszközök használatának gyakorisága a földrajzórákon

arról, hogy legalább tanulópáronként tudjanak atlaszból dolgozni. Sok helyen az iskolai könyvtári atlaszokat használják, vagy bent tartják a tanteremben, hogy ne kelljen „hazacipelni” és ne kapjanak elégtelent azért, mert nincs ott az órán. Ezért aztán nem csodálkozhatunk azon sem, hogy a tanulók bevallása szerint mindössze 18,6\%-uk tanul atlasszal otthon! Így érthetővé válik, miért is nehéz tanulni a topográfiai tananyagot.

A tankönyv tanórai használata is jelentősen visszaesett. 2009-ben még 73\% körül volt, 2016-ban a válaszadóknak már csak alig több mint a fele használja rendszeresen és gyakran. Vajon hogyan sajátítják el a tanulók a tankönyvből (mint nyomtatott információhordozóból) való tanulás módszereit? Talán nincs is rá szükség, hiszen otthoni tanuláshoz 43,2\% használja, de egyharmaduk mindössze egyszeri elolvasásra. A felmérés 
szerint a tanulók több mint a fele egyáltalán nem használ munkafüzetet az órán. Igaz, ez adódik abból, hogy a válaszolók nagy része középiskolai tanuló volt, ahol korábban nem volt ilyen taneszköz, ma pedig hiába van, a földrajztanárok nem ismerték fel a benne rejlő tanulási lehetőségeket. Amolyan felesleges és plusz anyagi tételt jelentő eszközként értelmezik. Általános iskolában (ahol hagyományosan az 1950-es évek óta használnak munkafüzetet) elterjedt az a gyakorlat, hogy amelyik munkafüzeti feladatot nem sikerült megoldani az órán, azt otthon kell megcsinálni. Ez a tanulókra mért „büntetés” nem valószínű, hogy segít elfogadhatóvá tenni számukra a taneszközt, annak ellenére sem, hogy azok már színesek és nemcsak rögzítési szerepet töltenek be, hanem sok gondolkodtató, újszerủ és érdekes feladatot tartalmaznak. A lányok csaknem kétszer szívesebben foglalkoznak munkafüzeti feladatmegoldásokkal, mint a fiúk.

A többi taneszköz használata még alárendeltebb. Vajon hogyan lehetséges a képi és virtuális alapú világban, hogy a tanítási-tanulási folyamatban nem használunk filmeket, modelleket a valóság megismeréséhez? Hát csoda, hogy a tanulók nem értik meg a tananyagot és nem látják a mindennapi élettel való kapcsolatát? Hogyan lehet érvelni, vitatkozni adatok, források, szemelvények elemzése nélkül? Hogyan taníthatók meg az információ gyűjtésének és feldolgozásának módszerei, ha nem kell az iskolában ilyet csinálni, ha nincs internetelérhetőség, számítógép a tanteremben? És természetesen a tantervi követelmények sem teljesíthetők laboratóriumi eszközök, homokasztal, tájoló, GPS vagy okostelefonos alkalmazások használata nélkül. Rendszeresen tapasztalom, hogy okostelefont nem szabad használni az iskolában tanulási célra sem, sőt, azokat begyüjtik a tanórák előtt. Pedagógiai indokai mégcsak beláthatók, de ez a gyakorlat tanulásmódszertani szempontból értelmezhetetlen és káros. Úgy tűnik, hogy a tanítás fogalma kezd azonosodni a prezentációvetítéssel (a földrajztanárok háromnegyed része használja gyakran vagy minden órán), már persze ahol van projektor. Ahol nincs, ott marad a vázlat- vagy jegyzetdiktálás. Kinek a felelőssége mindez? A tanárképzésé? Részben, hiszen ott sem adottak a technikai feltételek, tehát ezen eszközök használatának módszertani kultúrája nem tud szervesen beleépülni a tanári pályára való felkészülés folyamatába. A minősítési rendszeré, amiben a földrajz szakmódszertanhoz nem értő „szakértők” minősítik a szaktanárok munkáját? Az iskolavezetésé vagy a fenntartóké, akik nem biztosítják a tárgyi feltételeket?

Még ennél is elgondolkodtatóbb, hogy az elvileg a 21. század kihívásaira felkészítő iskolában milyen csekély arányban használják az informatikai eszközöket. De még csak nem is arról van szó, hogy az iskola falai között, hanem általában a tanulók alig 


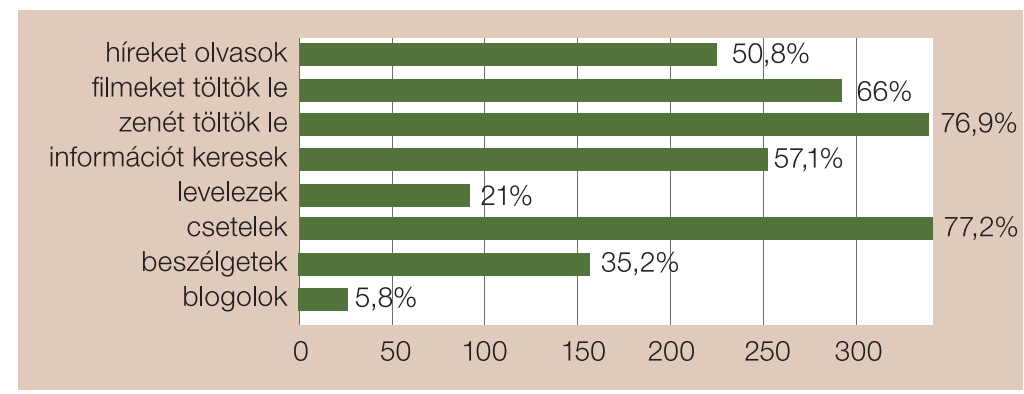

5. ábra. Digitális programok és alkalmazások használatának gyakorisága

használják az információszerzés, leképezés és feldolgozás eszközeként (5. ábra). A szövegszerkesztő és a prezenációkészítő alkalmazások, a térképi programok, az adatkezelő, a menetrendi alkalmazások használatának gyakorisága nagyon kicsi (összesítve a „havonta egyszer vagy soha" válaszok aránya $89 \%$ ). Ugyanakkor a kommunikációs és közösségi alkalmazások használatának gyakorisága kiemelkedően magas (a tanulók 65\%-a használja napi rendszerességgel), nem sokkal marad el mögöttük a zeneletöltés (76,9\%) sem. Sajnos azonban ennek sem örülhetünk, mert független az iskolai munkától, használatuk nem jelenik meg a tanulási célú alkalmazásokban.

\section{Foglalkozzunk-e a tanórán kívül is földrajzzal?}

A tanulás rendszeres tanórai közös és otthoni egyéni munkát feltételez. Az iskolai és az otthoni tanulás aránya is átalakulóban van. Többféle pedagógiai álláspont van ezzel kapcsolatban - egy olyan skálán, amelynek a két végpontját a „minden órára” és a „sohasem kell lennie" válaszok adják -, amelyek többsége el is fogadható. A felmérés azt mutatja, hogy a tanulóknak csak egyharmad része foglalkozik rendszeresen otthon földrajzzal (6. ábra). Tanulásmódszertani szempontból kifejezetten káros annak a tanári felfogásnak a terjedése, hogy otthon nem kell, nem szabad foglalkozni a tantárggyal. A tanítási órán ugyanis egyre kevésbé kerül mélységében feldolgozásra a tananyag, és különösen nem minden része. Minél kevesebb idő jut a tananyag tanórai feldolgozására, annál inkább nőnie kellene az otthoni tanulás arányának. Ezzel szemben az látjuk, hogy csökken (2009-ben még 59,5\% volt!). Az is kiderül a tanulók válaszaiból, hogy a tanulásnak csak célorientáltan látják értelmét. Tanulnak, ha dolgozat vagy feleltetés várható, különben minek? Természetesen életkoruknál és tapaszalatuknál fogva nem várható el tőlük, hogy értsék a tudásépítkezés természetét, hogy a tanulásnak csak akkor van értelme, ha rendszeres, ha a már meglévő elemekhez illesztjük az újakat, más rendszerbe helyezzük a meglévő tudáselemeket 


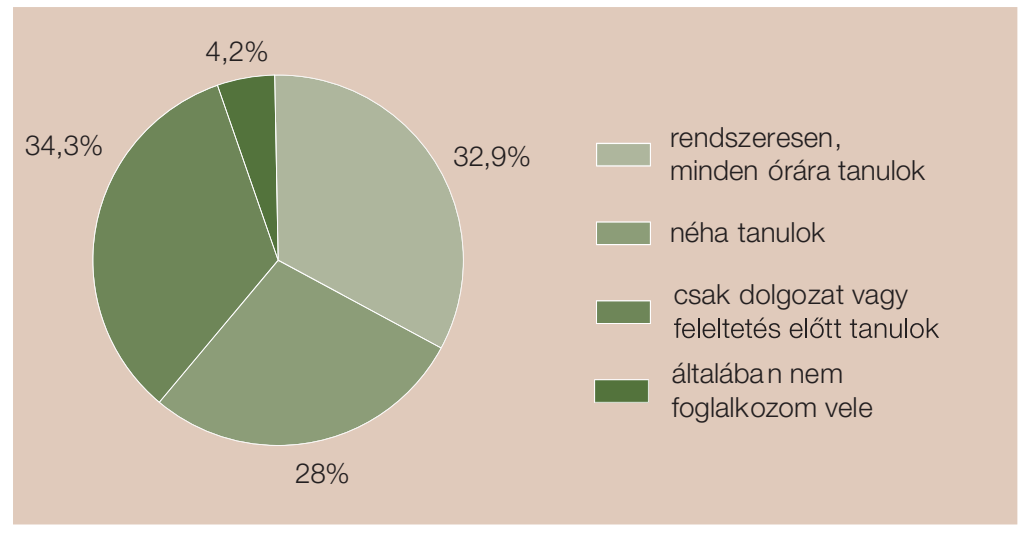

6. ábra. Az otthoni földrajztanulás rendszeressége

(információkat, tényeket és a velük való bánást, képességeket), vagy más logika szerint is végiggondoljuk a dolgokat, mint korábban. Azonban a tanáraiktól elvárható, hogy tényleg így építsék fokról fokra a tanulói tudásrendszert. Nem pedig minden órán új és még újabb fejezetet nyitni, és zúdítani a tanulókra a feldolgozatlan tudáselemeket, lehetőleg minél többet.

Ha így folyik a tanítási óra, a tanulók indokoltan gondolják úgy, hogy a tanulás lényege a szakkifejezések, a topográfiai fogalmak, a tények halmazának a memorizálása. Ebből pedig elegük van a tanítási órán, nemhogy még otthon is az várjon rájuk. Egyharmad részük inkább kerüli is (a felmérés ritkán vagy soha válaszai). Ha mégis érzik a tanórán kívüli tanulás fontosságát (akárcsak kötelességtudatból vagy kudarckerülésből is), vajon mennyit ér a válaszolók csaknem fele által említett 15 percnél rövidebb időtartamú tanulás (7. ábra)? Ez az órán elhangzott információk felelevenítésére sem elegendő, nemhogy tudatosulásra, gondolkodásra, rögzítésre, esetleg begyakorlásra. Amúgy a tanulás a gyerekek többségének $(83,7 \%)$ a fejében azonos az órai vázlat, jegyzet átolvasásával (8. ábra). Ök a tankönyvi leckéket nem is olvassák el (79,1\%-uk) és atlaszt sem használnak tanulásukhoz (95,3\%).

Van tehát értelme földrajzi házi feladatot adni a tanulóknak? Válaszolni nem könnyü annak meghatározása nélkül. Mint ahogyan a tanulók (72,3\%), úgy a tanárok gondolkodásában is a házi feladat nagyobb része a tanulnivaló, kisebb része az írásbeli feladat, fóleg azokban az osztályokban, ahol munkafüzetet is használnak (40,3\%) (8. ábra). Az írásbeli feladatok ellenőrizhetők, legalábbis annyira, hogy elkészültek-e vagy sem (31,0\%). Ennek persze önmagában nem sok értelme van, mert nem informálnak tartalmi és képességbeli 


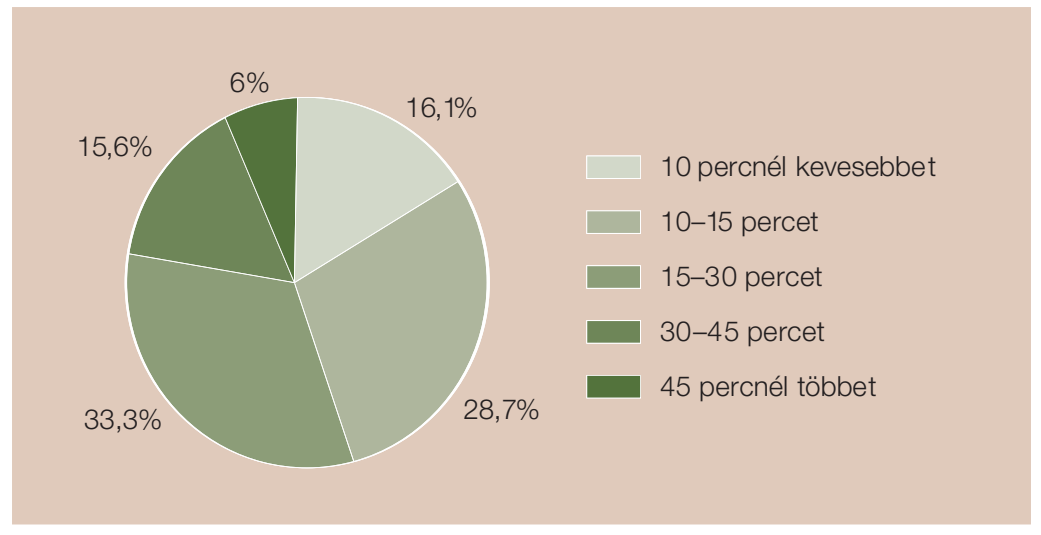

7. ábra. Az otthoni földrajztanulásra fordított idő alkalmanként

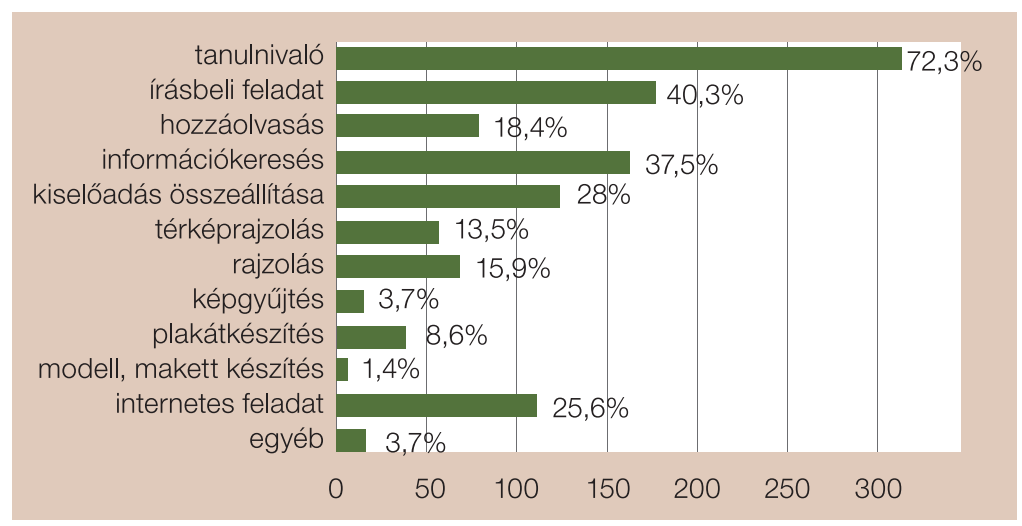

8. ábra. A földrajzi házi feladatok jellege

dolgokról. A tanulás azonban nem egy-egy munkafüzeti feladat megoldását jelenti. Olyan feladatokat kellene kapniuk a tanulóknak, amelyek alkalmat adnak arra, hogy a két egymást követő földrajzóra között eltelt egy hétben is foglalkozzanak a földrajzzal. Nem rutinszerűen megoldható (vagy lemásolható) feladatokkal, hanem információkeresési és információfeldolgozási, kutatási és felfedezési lehetőségeken keresztül. Csakhogy az ilyen típusú feladatok érdembeli elökészítést, értékelést és utólagos feldolgozást igényelnek, aminek gyakorlata ugyancsak hiányos (9. ábra). Az értékelés gyakran csak két számszerű szélső érték, jeles vagy elégtelen, azon az alapon, hogy elkészült vagy sem. Érdekes összefüggés mutatkozik az ilyen értékelés és a tanítási órák módszerei között. Ahol rendszeresen így osztályozza a tanár a házi feladatot, ott szinte csak frontális óravezetéssel, tanári előadással és magyarázattal „dolgoznak” az órákon (95,4\%). Jól mutatja ez (is) a hatalomelvű tanár-tanuló viszonyra épülő iskolai gyakorlatot. 


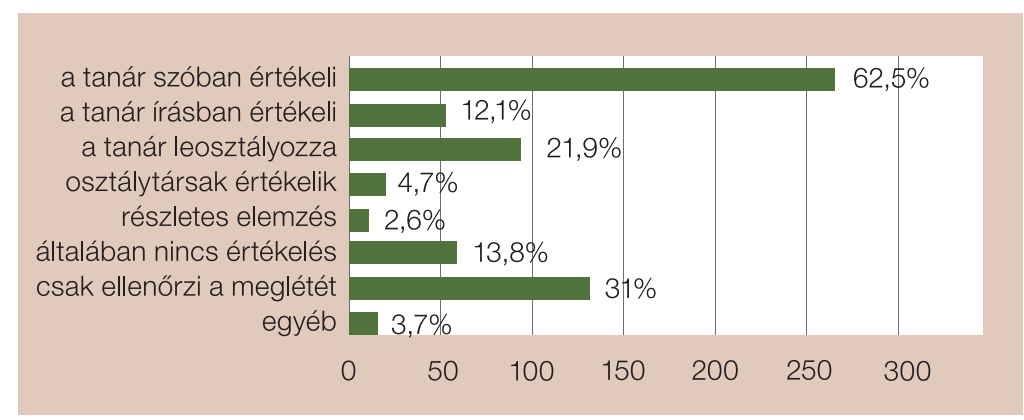

9. ábra. A földrajzi házi feladatok értékelése

\section{Szakadék a tudás és a tudásgazdaság között}

Földrajzórákon megtanulják a tanulók, hogy a világnak ma nem azok a sikertermékei, amelyek sok, drága anyagból és energiával készülnek, amikbe sok kézi vagy gépi munkát fektettek, hanem azok, amelyek sok apró speciális tudás összerakásán alapszanak. Ez a tudásgazdaság lényege. Csakhogy ez újfajta kommunikációs és munkaformákat igényel, olyanokat, amelyekben közösen hoznak létre értékeket, mindenki beleteszi a saját szaktudását, nézőpontját, de közösen érlelik, csiszolják. Ezt a fajta csapatmunkát és kommunikációt, másként a tanulást az iskolában kell elsajátítaniuk a tanulóknak ahhoz, hogy kifejlesztett 21. századi képességeikkel kelendők legyenek a munkaerőpiacon (Trilling, B.-FAdel, C. 2012). Ha ebbe belegondolunk, az iskolai munkának, a tanítás-tanulás folyamatának ezen kell alapulnia. S milyen messze van ettől a jelenlegi magyar földrajztanítás! Nem tanítjuk meg a tanulókat közösen gondolkodni, dolgozni, egyáltalán tanulni. Eszköz- és időhiány, szemléleti és módszertani hiányosságok miatt mintha épp ellenkező lenne az irány. Meggyőződésem, hogy egyetlen személy tud ezen változtatni, a földrajztanár, ott, helyben, saját tanítványai tudásszintjének, képességeinek, helyzetének ismeretében, a problémát megoldani akaró ambíciójával.

\section{Irodalom}

FARsAng A. 2011: Földrajztanítás korszerüen. GeoLitera, Szeged. 196 p.

MakÁDi M. 2011: A földrajztanárok módszertani kultúrája. Földrajzi Közlemények, 135. 2. pp. $125-133$.

MakÁdi M.-HoRváth G. 2011: A földrajz és a természettudományok. Földrajzi Közlemények 135. 2. pp. $179-184$.

Makádi M.-FArkas B. P.-Horváth G. 2013a: Tanulási-tanítási technikák a földrajztanításban. Egyetemi jegyzet. ELTE TTK-Prompt, Budapest, 275 p. 
Makádi M.-Horváth G.-Farkas B. P. 2013b: Vizsgálódási és bemutatási gyakorlatok a földrajztanításban. Egyetemi jegyzet. ELTE TTK-Prompt, Budapest, 279 p.

MAKÁDi M. 2015a: Tevékenykedtető módszerek a földrajztanításban. Szakmódszertani tankönyv. ELTE TTK, Budapest, 185 p.

MAKÁDI M. et al. 2015b: A természetismeret tanítása és tanulása. Szakmódszertani tankönyv. ELTE TTK, Budapest, $424 \mathrm{p}$.

Trilling, B.-FAdel, C. 2012: Partnership for 21st century skills. Learning for life in our times. JosseyBass, $256 \mathrm{p}$. 